\title{
ASPEK WACANA DALAM CERITA ANAK BERBAHASA INGGRIS
}

\author{
Nur Fatimah \\ FKIP Universitas Ahmad Dahlan Yogyakarta \\ e-mail: nur_fatimah@uad.ac.id
}

\begin{abstract}
This study aims to describe cohesive devices, discourse making elements, and children's characters in children's English stories. This study employed the microstructural and macrostructural discourse analysis. The data source was http:// www.britishcouncil.org/ kids/stories. The findings are as follows. First, the English stories under study use cohesive devices such as references, substitutions, ellipses, and conjunctions. Second, the stories present positive descriptions of children, showing that they can get along well, are pleasant, are altruistic, are close to families and friends, have dynamic and creative activities, and can solve problems.
\end{abstract}

Keywords: stories, grammatical analysis, lexical analysis, context

\section{PENDAHULUAN}

Buku cerita anak dalam bahasa Inggris, apalagi yang ditujukan untuk meningkatkan kemampuan anak dalam berbahasa Inggris memiliki beberapa hal penting. Selain ilustrasi, gambar yang menarik, buku cerita bahasa Inggris untuk anak memuat aspek kebahasaannya juga. Apakah bahasa Inggris di dalam cerita itu memang sesuai untuk anak? Bagaimana isi cerita anak itu? Apakah ada nilai positif bagi anak dari cerita itu? Bagaimana pencitraan karakter anak di cerita anak? Bagaimana pengaruh cerita anak terhadap perkembangan kepribadian anak? Apakah cerita memberikan pengaruh yang positif terhadap anak? Apakah cerita anak sudah memperhatikan perkembangan anak? Bertolak dari pertanyaan-pertanyaan sederhana itu, kegiatan penelitian bermaksud untuk mengetahui lebih dalam aspek-aspek wacana dalam cerita anak yang dapat digunakan untuk pengajaran bahasa Inggris sebagai bahasa asing.

Menganalisis cerita - cerita tersebut sudah seharusnya tidak terbatas pada aspek surface structure sekedar melihat susunan kata-kata yang tertata. Lebih dari itu kandungan cerita yang kaya harus dilihat lebih dalam lagi. Unsur-unsur yang berhubungan dengan konteks terjadinya peristiwa perlu dilihat untuk menangkap makna yang lebih komprehensif dari cerita-cerita itu.

Oleh karenanya, analisis wacana diperlukan supaya penikmat cerita dapat mengerti tidak hanya aspek bentuk dan makna dari teks tertulis tersebut tapi juga konteks yang melingkupi karya yang diteliti. Analisis wacana memungkinkan orang mengetahui sesuatu di balik yang tertulis. Melalui analisis wacana diperoleh penafsiran mengenai konteks-konteks yang melingkupi suatu karya. Konteks- konteks itu dapat muncul dalam konteks kultural, situasi, fisik, epistemis, dan konteks sosial. Semua konteks itu berjalin berkelindan membentuk hubungan membangun satu wacana utuh mengenai anak.

Anak bukan orang dewasa. Dia memiliki karakteristik sendiri. Menurut Slattery dan Willis (2001) anak- anak sedang mengalami perkembangan fisik dan psikologi yang pesat dan diliputi 
rasa ingin tahu yang tinggi. Anak-anak suka belajar dengan berbagai cara. Mereka suka bermain dan berimajinasi. Selain itu, mereka memahami situasi dengan petunjuk nonverbal, bukan dengan penjelasan tentang bahasa. Mereka menikmati sesuatu yang rutin dan diulangulang. Akan tetapi, perlu diingat juga bahwa mereka memiliki perhatian yang singkat. Selanjutnya, ada pula ciri lainnya. Anak-anak tertarik dengan hal-hal yang "kini dan sini" yang ada di sekitar mereka. Hurlock (1978) menyatakan di masa kanak-kanak individu bersifat egosentris.

Meskipun mengalami perkembangan dari waktu ke waktu, cerita tetap memuat hal-hal penting. Di antaranya adalah bahwa cerita mengandung kisah, nilai- nilai budaya dan sosial, serta pengembangan imajinasi. Morrow (1993) berpendapat bahwa cerita membantu anak memperoleh kemampuan membaca. Cerita yang diulang-ulang membantu mengembangkan konsep mengenai kata, tulisan dan buku serta sikap positif dalam membaca, meningkatkan penguasaan kosakata dan mendapatkan pengalaman dalam berbahasa.

Untuk mengerti apakah suatu cerita dapat digunakan untuk pengajaran bahasa, pengguna cerita perlu memperhatikan hal-hal berikut. Sebagai contoh, dari aspek bahasa, yang perlu dicermati adalah apakah terdapat paralelisme, kekayaan kosakata, aliterasi, kontras, metafora, intertekstualitas, narasi, dan dialog yang ada dalam cerita anak (Cameron, 2001). Aspek lain yang perlu menjadi perhatian adalah apakah ada struktur bahasa tertentu yang diberi penekanan, pengulangan dalam penggunaan unsur bahasa tertentu (formulaic language), dan aspek kebahasaan lainnya dalam cerita.

Cerita yang baik menurut Marrow (1993) adalah cerita yang terstruktur. Di dalamnya ada latar, tema, kejadian-kejadian yang menunjukkan aktivitas tokoh dalam menyelesaikan masalah dan resolusi atau penyelesaian masalah dan akhir cerita itu. Cerita dengan demikian dapat memberikan pengaruh kepada pembacanya termasuk anak.

Melalui cerita, seorang penulis mengkomunikasikan gagasannya kepada pembaca. Komunikasi yang terbangun di antara keduanya disampaikan dalam bentuk kode-kode bahasa atau ujaran pada konteks tertentu. Dalam peristiwa seperti ini, istilah wacana dapat dimunculkan.

Wacana (discourse, berasal dari discursus) adalah satuan bahasa yang lengkap, sehingga dalam hierarki gramatikal merupakan satuan gramatikal tertinggi atau terbesar (Chaer dalam Sumarlam (2003). Dalam wacana terdapat ekpresi ide yang umumnya di atas level kalimat yang memiliki kohesi dan koherensi sehingga pesan yang ada dapat dipahami oleh pihak - pihak yang melakukan komunikasi.

Ide ini sejalan dengan pendapat J.S. Badudu (dalam Eriyanto (2001: 2). Wacana oleh Badudu dinyatakan sebagai

Kesatuan bahasa yang terlengkap dan tertinggi atau terbesar di atas kalimat atau klausa dengan koherensi dan kohesi yang tinggi yang berkesinambungan, yang mampu mempunyai awal dan akhir yang nyata, disampaikan secara lisan atau tertulis.

Penulis juga bersinggungan dengan wacana di saat menyampaikan gagasannya lewat karya sastra yang dihasilkannya. Cerita yang ditulis misalnya, tidak bisa dilepaskan dari aspek wacana. Dalam cerita, selain terdiri dari rangkaian kata-kata, padanya juga memuat konteks jamannya. Isi cerita merefleksikan fenomena sosial di wak- 
tu tertentu. Sehingga mendiskusikan isi cerita seharusnya tidak hanya aspek bentuk tapi juga makna dan konteksnya.

Konteks dalam pemakaian bahasa dapat dibedakan menjadi empat. Keempat konteks itu adalah konteks fisik, konteks epistemis atau latar belakang, konteks linguistik atau konteks, dan konteks sosial. Tempat terjadinya komunikasi, latar belakang pembicara/ penulis dan pendengar/pembaca, ujaran atau kalimat lain yang menyertai dan relasi sosial dan latar mempengaruhi pemakaian bahasa.

Pada telaah karya sastra, analisis wacana diperlukan untuk mendapat pemahaman yang komprehensif terhadap isi karya sastra itu. Karena bahasa terdiri atas bentuk dan makna, maka kajian terhadap karya sastra seperti cerita perlu dilihat dari struktur lahir dan struktur batinnya. Dengan kata lain, karya sastra tersebut ditilik dengan pendekatan mikrostruktural yakni kohesi yang merupakan aspek gramatikal wacana dan koherensinya yang merupakan aspek leksikal wacana dan pendekatan makrostruktural dengan menganalisis konteks yang melingkupinya (Sumarlam, 2003). Analisis wacana memiliki kelebihan karena analisis ini tidak hanya membantu untuk mengetahui bagaimana isi teks berita tapi juga mengetahui bagaimana pesan itu disampaikan (Sobur, 2002).

Sebagaimana disebutkan sebelumnya, pesan yang menjadi muatan cerita dapat dicermati dari berbagai pendekatan. Menurut Sumarlam (2003) kohesi yang ada pada cerita dapat diketahui melalui pendekatan mikrostruktural. Sebagai contoh, aspek gramatikalnya dapat ditelusuri melalui pengacuan (reference: persona, demonstratif waktu dan tempat, komparatif), penyulihan (substitution: nominal, verbal, frasal, klausal), pelesapan (ellipsis) dan perangkaian (conjunctions: penanda hubungan sebab akibat, pertentangan, additif, sekuensial, waktu, cara, dll.).

Lebih lanjut, aspek leksikalnya dapat diperoleh dari pengulangan (repetisi), padan kata (sinonimi), sanding kata (kolokasi), hubungan atasbawah (hiponimi), lawan kata (antonimi: oposisi mutlak, kutub, hubungan, hirarkial) dan kesepadanan (ekuivalensi). Pendekatan makrostruktural lebih berkait dengan masalah konteks situasi dan budaya. Menurut Fanani (1995) deskripsi tentang nilai mengacu pada ringkasan cerita, inti dan tema cerita. Sebagai contoh, melalui cerita dapat diperkenalkan nilai-nilai pendidikan, sifat cerdik dan pandai, kasih sayang dan sebagainya.

Melalui analisis wacana tersebut, wacana anak cerita anak berbahasa Inggris dapat didiskusikan. Pada tokoh-tokoh anak yang muncul karakter anak dapat diteliti, seperti apakah anak dan lingkungan berkembangnya yang terefleksikan pada diri tokoh-tokoh tersebut.

Melalui analisis wacana yang diterapkan, sisi-sisi yang menyangkut kebahasaan akan bisa diketahui. Selain itu, aspek konteks sosial pun akan dapat dibahas secara menyeluruh melalui analisis wacana yang diterapkan pada cerita - cerita yang digunakan untuk pendidikan dan pengajaran kepada anak.

Dengan demikian, hasil penelitian yang membahas analisis wacana mengenai anak tersebut akan sangat membantu dalam mengambil keputusan berkait pendidikan dan pengajaran anak. Cerita dapat berperan dalam pembentukan konsep diri anak tentang siapa dan apa dia sebagai manusia (Hurlock, 1978). Zipes, dan Morgan dan Rinvolucri (dalam Mixon dan Temu, 2006) menyatakan bahwa cerita merupakan bagian dasar dari pendekatan whole lan- 
guage untuk melakukan pembelajaran dalam rangka mencapai whole person (manusia seutuhnya) dan untuk memberi masukan terhadap kondisi subconscious (a basic part of the whole language approach to learning, reaching the "whole person" and appealing to subconscious).

Konsep diri yang dimiliki anak dipengaruhi oleh beberapa hal. Menurut Crow dan Crow (dalam Hurlock, 1978) konsep diri di masa kanak-kanak adalah dampak atau akibat pengaruh dari 12 faktor yang melingkupi anakanak. Faktor-faktor itu adalah harapan orang tua, sikap terhadap anggota keluarga, keadaan fisik anak, kematangan biologis, pengaruh media, kesempatan sekolah, tuntutan sekolah, agama, pendapat sebaya, masalah ekonomi keluarga, masalah pribadi keluarga, dan sikap terhadap teman sebaya.

Menurut Nurgiyantoro (2005), cerita sebagai bagian dari wujud sastra anak memberikan setidaknya nilai personal dan nilai pendidikan. Berkait nilai personal, cerita mempengaruhi perkembangan emosional, intelektual, imajinasi, pertumbuhan rasa sosial, rasa etis dan religius. Dalam hal nilai pendidikan, cerita berpengaruh pada eksplorasi anak, perkembangan bahasanya, perkembangan nilai keindahan, penanaman wawasan multikultural dan kebiasaan membaca. Berdasar penjelasan tersebut, cerita berpeluang untuk memberikan kontribusi pada pembentukan diri anak.

Pollard (http://www.ialf.edu/kipbipa/papers/) melakukan penelitian tentang pemanfaatan sastra lisan dalam pengajaran bahasa Indonesia kepada pembelajar Australia. Pollard membahas keunggulan dan kelemahan menggunakan cerita tradisi lisan dan tentang ketertarikan pembelajar asing atas cerita tradisional dibandingkan dengan pengajaran konvensional. Yang juga dikupas adalah apakah cerita tradisi lisan menempati posisi penting dalam pengajaran bahasa Indonesia atau merupakan pelengkap saja. Perhatian pembelajar asing terhadap nilai-nilai budaya yang ada dalam cerita tradisi lisan tersebut juga dianalisis.

Masih terkait cerita dan anak, Riris K Toha-Sarumpaet menyajikan hasil studinya pada forum HISKI 2004 di Yogyakarta. Yang dikaji adalah Sastra dan Anak: Penjajah dan Taklukannya. Temuannya menunjukkan bahwa cerita anak tidak menempatkan anak sebagai tokoh sentral. Tokoh anak ternyata lebih banyak sebagai jalan masuknya ide-ide orang dewasa (orang tua). Karakter anak dalam cerita anak tidak menampilkan dirinya sebagai anak-anak.

Gagasan lain terkait cerita dan anak disampaikan oleh Plaskota (http:// www. dominican. edu/). Menurutnya, membaca dan cerita dapat memberikan pengaruh pada pembentukan spiritual anak-anak. Yang dimaksud adalah pembentukan identitas dan pengenalan kemampuan spiritual anak.

\section{METODE}

Penelitian ini menggunakan pendekatan mikrostruktural dan makrostruktural. Data berupa wacana deskriptif naratif diperoleh dari wacana cerita anak berbahasa Inggris dari situs http://www.britishcouncil.org/kids/stories. Pada situs tersebut terwakili beberapa genre dalam sastra anak seperti folktale, fabel, fantasi dll (Lukens, 1999).

Jenis cerita yang dijadikan sumber data adalah cerita little kids. Hal itu dengan pertimbangan bahwa jenis cerita tersebut dapat dipakai dalam kelas bahasa Inggris di sekolah dasar Indonesia mengingat isi, panjang cerita dan kompleksitas pemakaian bahasa bagi siswa Indonesia yang belajar bahasa Inggris. Cerita yang dijadikan sumber data, yaitu: The Greedy Hippo, The Monster Shop- 
ping Trip, The Twins Week, Teddy's Adventure, Eric the Engine and The Rail Way Rock, The Magic Spell, dan The Princess and the Dragon. Untuk memperoleh data tersebut, dilakukan pembacaan secara mendalam cerita-cerita anak yang dijadikan sumber data.

Langkah-langkah penelitian yang dilakukan meliputi pengumpulan data, klasifikasi data, analisis mikro dan makrostruktural. Setelah itu dilakukan penafsiran terhadap data yang masuk berdasarkan teori tentang analisis wacana. Aspek yang diangkat untuk diteliti meliputi bentuk (form) dan makna (meaning). Tidak hanya aspek leksikal yang dicermati, tapi juga kohesi supaya data yang diperoleh untuk menjawab pertanyaan penelitian tidak hanya berdasar pada rangkaian kata yang sifatnya permukaan.

\section{HASIL DAN PEMBAHASAN}

Cerita-cerita yang diteliti menampilkan alat-alat kohesi yakni semua aspek yang termasuk dalam aspek gramatikal yang diteliti dengan analisis wacana. Aspek-aspek tersebut meliputi referensi, substitusi, elipsis dan konjungsi.

Pada The Magic Spell dan The Princess and the Dragon tidak ditemukan sinonimi. Sementara antonimi tidak disajikan pada The Twins Week. Cerita The Greedy Hippo tidak memuat ekuivalensi. Ketiadaan aspek leksikal itu tidak mengurangi kejelasan untuk memperoleh gambaran tentang profil anak karena ada konteks situasi dan budaya yang melingkupi cerita-cerita yang diteliti.

Untuk memberi deskripsi yang lebih jelas mengenai hasil kajian, berikut satu contoh penjelasan dari salah satu cerita yang diteliti. Cerita The Monster Shopping Trip menggunakan referensi persona pertama, dan ketiga (tunggal dan jamak). Sebagai contoh adalah
(1) Hairy Henry is a handsome green monster. He lives in a small house in the forest.

(2) Loony Lou and Gorgonzola just don't know what to buy him. ... they got the train to London.

(3) I know just the place...

Terkait dengan pemakaian referensi terhadap tempat dan waktu, The Monster Shopping Trip juga memilikinya. Penggunaan time reference sebagai referensi demonstratif berupa kata ganti penunjuk muncul dalam forest (data 1), London (data 2), station, computer shop, next.

Sisi lain dalam kohesi gramatikal adalah substitusi. Yang demikian itu tampak pada penggunaan present yang ditunjukkan dengan substitusi frasa pada:

(4) ...a present. "What about a camera?"

(5) "Let's buy him a new pair of shoes."

Berikutnya adalah jenis kohesi gramatikal pelesapan. Dalam cerita The Monster Shopping Trip dimunculkan elipsis ekuivalensi nomina dan pelesapan subjek, seperti pada

(6) "What about (buying him) a camera?"

(7) We can visit Hairy Henry's cousin Big Ben and (we) ask him...

Untuk kohesi gramatikal berupa perangkaian (konjungsi), pada cerita yang diteliti muncul pada data berikut. Dalam data (7) terdapat konjungsi and yang menunjukkan hubungan additif. Contoh lainnya adalah

(8) But then Hairy Henry is deserves it as he is such a nice monster. (hubungan sebab)

Kohesi leksikal pada The Monster Shopping Trip dapat dijelaskan melalui data-data sebagai berikut. 
(9) Loony Lou and Gorgonzola... (repetisi bunyi)

(10) "What about a camera?" “No, he's got a camera." (repetisi kata)

(11) So they go the train...Big Ben waited for them...(sinonimi)

(17) ...catching horrible human....such a nice monster. (antonimi)

(18) birthday..., present, cake (kolokasi)

(19) ...got the train.....waited for them at the station...(kolokasi)

(20) ...buy him a present...camera, chocolates, short (hiponimi)

(21) shop...computer shop, cake shop (hiponimi)

(22) Everything was monstrously monstrous (ekuivalensi)

Selanjutnya, berikut penjelasan mengenai tema, penokohan, alur, latar cerita The Monster Shopping Trip. Cerita ini mengisahkan monster persahabatan Hairy Henry dengan Loony Lou dan Gorgonzola. Hairy Henry adalah teman yang disukai sehingga pad hari ulang tahunnya, teman-temannya mencarikan hadiah menarik untuknya. Alur bersifat progresif dengan latar pendukung yakni waktu (soon, birthday) dan tempat (London, station, computer shop, cake shop).

Bagian berikutnya adalah analisis konteks untuk mendapatkan unsur-unsur pembentuk wacana. Dalam The Monster Shopping Trip, pembentuk wacana tersebut didukung oleh adanya data-data sebagaimana telah disajikan sehingga interpretasi mengenai konteks situasi dan sosial budaya serta figur tokoh (yang mewakili) anak bisa didapatkan.

(23) "Let's buy him a new pair of shorts."

(24) "I know!" said Loony Lou. Let's go shopping in London.

(25) "I know just the place," said Big Ben and they went shopping.
Hairy Henry dalam cerita tersebut secara eksplisit sudah dideskripsikan sebagai sosok monster yang tampan, cerdas, dan disenangi teman-temannya. Karenanya, pada hari ulang tahunnya, dia mendapat perhatian dari temantemannya. Mereka mencarikan hadiah yang menarik dan tepat, sampai-sampai mereka harus pergi ke London untuk mendapatkan hadiah itu. Big Ben sepupu Hairy Henry membantu Loony Lou dan Gorgonzola untuk tujuan itu. Kisah The Monster Shopping Trip menggambarkan ketulusan anak-anak dalam berteman dan kerelaan mereka untuk berusaha demi membahagiakan sahabat.

Kisah yang mirip dengan itu terjadi pada cerita Eric the Engine and the Railway Rock. Cerita ini mengisahkan Eric, si mesin yang menyelamatkan kepentingan umum. Hewan-hewan lain seperti rabbit, fox, mouse dan seagull awalnya ingin memindahkan batu penghalang supaya kereta dapat melaju dengan baik namun tak berhasil. Mereka kemudian memanggil Eric. Dari sini tampak alur bersifat progresif dengan latar pendukung yakni waktu (in one hour) dan tempat (here, on the train line, over the hill, over the cliff).

Dalam Eric the Engine and the Railway Road pembentuk wacana tersebut dapat dibantu oleh adanya data-data berikut sehingga interpretasi mengenai konteks situasi dan sosial budaya serta figur tokoh (yang mewakili) anak bisa didapatkan.

... "You go first, then you," and he sent his friends ahead. "I'll follow you."...

...He pushed the four engines and the four engines pushed the rock....

...The train blew its horn. "Thaaaaank Yooooooou"

Eric the Engine dalam cerita tersebut digambarkan sebagai sosik yang kuat, penolong dan dapat diandalkan. 
Teman-temannya (kelinci, serigala, tikus dan seagull mengetahui hal ini dan mempercayai dan mengandalkannya. Karenanya, ketika diperkirakan akan ada bahaya kecelakaan kereta api, mereka memanggil Eric untuk membantu usaha supaya musibah tidak terjadi dan mereka bekerja bersama-sama.

Dari Eric the Engine and the Railway Rock dapat diperoleh pesan moral tentang usaha bersama untuk kepentingan umum. Dengan mengetahui pihak mana yang dapat dimintai bantuan dan bagaimana mengusahakannya maka permasalahan dapat diselesaikan.

The Twins Week mengisahkan Kim dan Ken yang memiliki banyak aktivitas di kebun binatang tempat ayah mereka bekerja. Keduanya berteman dengan hewan -hewan yang ada di sana dan mereka selalu memiliki kegiatan yang menyenangkan setiap harinya. Alur bersifat progresif dengan latar pendukung yakni waktu (nama-nama hari, evening, night, lunch) dan tempat (zoo, park, pool, home).

Dalam The Twins Week pembentuk wacana tersebut dapat dibantu oleh adanya data berikut sehingga interpretasi mengenai konteks situasi dan sosial budaya serta figur tokoh (yang mewakili) anak bisa didapatkan.

...He has so many things to do. On Mondays they take a shower, the hippos join the fun. They watch TV with the fish, the week has just begun. On Tuesdays they eat breakfasts with the pandas and the frogs....

Dalam cerita The Twins Week tersebut dideskripsikan betapa pertemanan dengan hewan-hewan di kebun binatang dapat menyenangkan. Setiap hari dapat diisi dengan aktivitas yang menarik dan bermanfaat dengan mereka. Binatang yang dihadirkan tidak hanya binatang jinak seperti ikan, burung dan katak, tapi juga binatang buas seperti buaya dan kuda nil. Melalui paparan semacam ini anak-anak memperoleh jalan untuk menumbuhkan rasa cintanya kepada binatang.

Bagian berikutnya adalah ulasan mengenai cerita Teddy's Adventure. Cerita ini mengisahkan petualangan Teddy si boneka beruang yang berpindah-pindah tempat sampai akhirnya bertemu lagi dengan temannya Kumiko. Anjing di rumah menyebabkan Teddy sampai di tas belanja, ikut shopping, masuk trolley, tempat sampah, diambil burung, ditemukan orang dan sampai ke sekolah Kumiko, teman sekamarnya. Cerita mengalir maju atau dengan kata lain alurnya bersifat progresif dengan latar pendukung tempat (bedroom, school, building).

Selanjutnya dilakukan analisis konteks untuk mendapatkan unsur-unsur pembentuk wacana. Dalam Teddy's Adventure pembentuk wacana tersebut dapat dibantu oleh adanya data-data berikut sehingga interpretasi mengenai konteks situasi dan sosial budaya serta figur tokoh (yang mewakili) anak bisa didapatkan.

..."How did you come to school?" she asked....

...Teddy lay sadly on the bedroom floor, forgotten, when Kumiko went to Nursery school....

Teddy dalam cerita tersebut digambarkan sebagai sosok yang kesepian. Kumiko teman sekamarnya bersekolah. Karena perbuatan anjing di rumah, Ted$d y$ mengalami pengalaman mencekam sampai akhirnya bertemu lagi dengan Kumiko di sekolahnya.

Dari Teddy's Adventure dapat diperoleh pesan moral bahwa pengalaman yang kurang atau tidak menyenangkan dapat berujung pada sesuatu yang tak terduga. Ini seperti pertemuan Teddy 
dengan Kumiko.

Selanjutnya adalah pembahasan The Magic Spell. Cerita ini mengisahkan mimpi buruk yang dialami Billy. Mimpi ini berupa kegiatan coba-coba dan ceroboh yang dilakukan Billy dan Tom. Aktivitas ini menjadikan Billy seperti gajah. Dia tidak berhasil mencari obatnya meski sudah mencari di Internet. Cerita diakhiri dengan terbangunnya Billy yang kemudian mau pergi ke sekolah karena ternyata yang dikhawatirkannya hanyalah mimpi. Alur cerita bersifat progresif dengan latar pendukung waktu seperti nearly all night, dan next morning. cerita tersebut.

Dalam The Magic Spell pembentuk wacana tersebut dapat dibantu oleh adanya data-data berikut ini.

...'Don't be silly! What an excuse!' she said....

... 'Hooray! I can go to school.'...

Billy dalam cerita tersebut digambarkan bersemangat untuk bersekolah setelah menyadari bahwa dia hanya mimpi buruk. Dia meyakini itu setelah mendengarkan ekspresi dari Ibunya. Dari The Magic Spell diperoleh pesan moral bahwa pengalaman anak dapat memberi kesan mendalam dan terbawa mimpi.

Selanjutnya dijelaskan hasil kajian The Princess and the Dragon. Cerita ini berisi kebaikan yang membawa keberuntungan. Dragon yang akhirnya berhasil menyelamatkan princess mendapat hadiah tas berisi emas. Cerita mengalir maju atau dengan kata lain alurnya bersifat progresif dengan latar pendukung tempat (castle, tower, in the sky) dan waktu (once upon a time, night).

Dalam cerita itu dikisahkan kesedihan king dan queen ketika princess disekap dan rasa bahagia mereka setelah princess berhasil diselamatkan menunjukkan ikatan alami dan orang tua. Orang tua mau melakukan apa saja sebagai bentuk rasa berterima kasih kepada penyelamat anaknya. Princess yang mengalami penderitaan akhirnya ditolong dari dragon yang ramah.

...The king and queen were very sad. They promised to give a bag of gold...The dragon rescued the princess...The king and queen were so happy...they gave the dragon the bag of gold.

Secara ringkas, aspek-aspek gramatikal dan leksikal yang ada dalam masing-masing cerita dapat dicermati pada tabel 1.

Cerita-cerita yang diteliti memberikan gambaran positif tentang anak. Anak-anak diwujudkan sebagai sosok yang bisa bergaul, menyenangkan, memikirkan orang lain, memiliki kedekatan dengan keluarga dan teman, mempunyai aktivitas dinamis dan kreatif, dan memiliki ide cemerlang.

Dari ketujuh cerita yang diteliti, anak diperkenalkan dengan berbagai karakter yang ada. Secara garis besar, karakter tokoh diambilkan dari binatang (seperti dalam The Greedy Hippo), manusia (dalam The Twins Week, The Magic Spell, The Princess and the Dragon) dan yang bersifat nonmanusia seperti monster (dalam the Monster Shopping Trip) dan benda mati (dalam Teddy's Adventure dan Eric the Engine and the Railway Rock).

Tokoh utama dalam masing - masing cerita yang diwakili ditampilkan dalam sosok yang beragam. The Greedy Hippo menampilkan Hippo si kuda nil. Pada The Twins Week dijumpai si kembar bernama Kim dan Ken. Sementara The Magic Spell menampilkan Billy. Cerita The Princess and the Dragon diawali dengan cerita di sebuah kerajaan yang putri rajanya diculik. Untuk the Monster Shopping Trip, tokohnya monster cerdas dan baik hati yakni Hairy Henry. Selan- 
Tabel 1 Aspek Gramatikal dan Leksikal pada Cerita Anak

\begin{tabular}{lcccccccccc}
\hline \multicolumn{1}{c}{ Judul } & \multicolumn{3}{c}{ Aspek gramatikal } & \multicolumn{7}{c}{ Aspek Leksikal } \\
\hline & ref & sub & eli & konj & rep & sin & ant & kol & hip & eku \\
\hline $\begin{array}{l}\text { The Greedy Hippo } \\
\text { The Monster }\end{array}$ & $\sqrt{ }$ & $\sqrt{ }$ & $\sqrt{ }$ & $\sqrt{ }$ & $\sqrt{ }$ & $\sqrt{ }$ & $\sqrt{ }$ & $\sqrt{ }$ & $\sqrt{ }$ & - \\
$\begin{array}{l}\text { Shopping Trip } \\
\text { Eric the Engine and }\end{array}$ & $\sqrt{ }$ & $\sqrt{ }$ & $\sqrt{ }$ & $\sqrt{ }$ & $\sqrt{ }$ & $\sqrt{ }$ & $\sqrt{ }$ & $\sqrt{ }$ & $\sqrt{ }$ & $\sqrt{ }$ \\
the Railway Rock & & & $\sqrt{ }$ & $\sqrt{ }$ & $\sqrt{ }$ & $\sqrt{ }$ & $\sqrt{ }$ & $\sqrt{ }$ & $\sqrt{ }$ \\
The Twins Week & $\sqrt{ }$ & $\sqrt{ }$ & $\sqrt{ }$ & $\sqrt{ }$ & $\sqrt{ }$ & $\sqrt{ }$ & - & $\sqrt{ }$ & $\sqrt{ }$ & $\sqrt{ }$ \\
Teddy's Adventure & $\sqrt{ }$ & $\sqrt{ }$ & $\sqrt{ }$ & $\sqrt{ }$ & $\sqrt{ }$ & $\sqrt{ }$ & $\sqrt{ }$ & $\sqrt{ }$ & $\sqrt{ }$ & $\sqrt{ }$ \\
The Magic Spell & $\sqrt{ }$ & $\sqrt{ }$ & $\sqrt{ }$ & $\sqrt{ }$ & $\sqrt{ }$ & - & $\sqrt{ }$ & $\sqrt{ }$ & $\sqrt{ }$ & $\sqrt{ }$ \\
The Princess and the & $\sqrt{ }$ & $\sqrt{ }$ & $\sqrt{ }$ & $\sqrt{ }$ & $\sqrt{ }$ & - & $\sqrt{ }$ & $\sqrt{ }$ & $\sqrt{ }$ & $\sqrt{ }$ \\
Dragon & & & & & & & & & \\
\hline
\end{tabular}

Keterangan:

ref $=$ referensi

sub = substitusi

$\sin =$ sinonimi

eli = elipsis

kol $=$ kolokasi

konj = konjungsi

ant $=$ antonimi

hip = hiponimi

jutnya karakter dalam Teddy's Adventure berupa boneka beruang dan Eric the Engine and the Railway Rock memperkenalkan Eric si kereta penyelamat.

Profil anak digambarkan utuh dalam tokoh - tokoh tersebut. Hippo mewakilinya mengingat anak - anak berkembang fisik dan psikologisnya. Hippo suka makan dan memiliki sifat serakah dan egois. Sifat ini tentu saja negatif. Dia mendapatkan pelajaran dari teman - temannya yang membuat trik supaya jera.

The animals were angry, and thought they'd play a trick. They made a pie from fish and soap to make old Hippo sick. ... "I feel quite odd inside." Now he had a tummy ache as hte cooks looked on with pride. Hippo learnt his lesson. It was the end of all their troubles...

Tokoh Kim dan Ken digambarkan tinggal bersama orang tua di kebun binatang dan berinteraksi dengan satwa. Diceritakan bahwa anak-anak dapat bergaul baik di sana. Tidak hanya dengan binatang yang jinak (ikan, burung), dengan binatang buas (seperti buaya)

pun dikisahkan Kim dan Ken bisa.

Dalam The Magic Spell, Billy menampilkan sosok anak yang lazim punya pengalaman yang beragam. Yang dialaminya terbawa dalam mimpi buruk. Anak-anak kadang mengalami hal itu sehingga cemas dan khawatir. Semua keresahan itu dapat teratasi dengan peran Ibu setelah berakhirnya mimpi. Anak dapat beraktivitas seperti biasanya de-ngan riang yakni bersekolah.

Hubungan anak dengan orang tua demikian dekat. Hal ini ditemukan dalam cerita The Princess and the Dragon. Penculikan dan penyekapan anak membuat orang tua sedih. Princess, si anak yang diculik melakukan usaha untuk membuat pertolongan. Dalam hal ini tokoh anak digambarkan mampu mengusahakan pertolongan (dalam cerita ini dengan cara berteriak) sehingga akhirnya datang penolong (tokoh dragon) yang menyelamatkannya.

Cerita lainnya The Monster Shopping Trip memperkenalkan Hairy Henry yang tampan, cerdas dan baik hati. Karena sisi-sisi positifnya, dia disukai teman- temannya sehingga mereka rela berupaya keras untuk mengusahakan hadiah ulang tahun kepada teman yang 
disukainya. Anak-anak dalam cerita ini dilukiskan dengan sifat berani berinisiatif mengadakan perjalanan sendiri, mengusahakan keperluan sendiri, menjalin hubungan dengan pihak lain (diwakili Big Ben sepupu Hairy Henry) dan memberi kebahagiaan bagi temannya.

Pendeskripsian anak lebih beragam melalui Teddy's Adventure. Anakanak bisa mengalami seperti Teddy yang sendirian dan kemudian terlibat dalam petualangan mendebarkan. Akan tetapi semua itu berujung pada sesuatu yang tak terduga tapi menyenangkan, seperti bertemunya Teddy dengan $\mathrm{Ku}$ miko, teman sekamarnya di tempat Kumiko belajar. Pengalaman Teddy dapat memberikan optimisme bahwa hal yang mengenakkan, menyenangkan akan terjadi, kekhawatiran atau pengalaman yang tidak mengenakkan akan berakhir.

Anak - anak juga dapat melakukan tindakan berharga untuk banyak orang seperti ketika Eric yang menyelamatkan London train dari musibah. Eric yang bekerja sama dengan temantemannya berhasil menyingkirkan batu penghalang sehingga laju kereta London tetap bisa lancar sampai ke tujuan.

Akhirnya dapat disimpulkan bahwa cerita yang diteliti memberikan gambaran positif tentang anak. Mereka diwujudkan sebagai sosok yang bisa bergaul, menyenangkan, memikirkan orang lain, memiliki kedekatan dengan keluarga dan teman, mempunyai aktivitas dinamis dan kreatif, dan memiliki ide cemerlang.

Sifat- sifat tersebut diperkuat dengan penyajian cerita yang memperhatikan aspek gramatikal, leksikal dan konteks. Dari semua cerita yang diteliti, ditemukan adanya pengulangan-pengulangan. Di antara repetisi yang menjadi temuan adalah pemakaian nama diri secara berulang- ulang yang menyiratkan pentingnya kehadiran tokoh (anak) di dalam cerita.

Selain itu, meskipun ada tokoh bukan dari manusia, referensi persona yang digunakan bukanlah ' $i t^{\prime}$ yang dapat diartikan bahwa eksistensi si tokoh diakui bukan sebagai benda (bandingkan dengan diperkenalkan Dave dalam The Lost Boy. Di dalamnya kepada tokoh anak laki - laki tidak digunakan he tapi it).

\section{SIMPULAN}

Cerita-cerita little kids dapat dipakai untuk pengajaran bahasa Inggris kepada anak-anak Sekolah Dasar. Bentuk bahasa dan isi ceritanya menampilkan banyak aspek yang mendukung pembelajaran bahasa Inggris kepada anak-anak. Cerita-cerita yang diteliti menampilkan alat-alat kohesi yakni semua aspek gramatikal yang diteliti dengan analisis wacana. Aspekaspek tersebut meliputi referensi, substitusi, elipsis dan konjungsi.

Kelebihan lain cerita-cerita tersebut adalah adanya pesan-pesan moral yang berguna untuk perkembangan anak. Cerita-cerita yang diteliti memberikan gambaran positif tentang anak. Anak-anak diwujudkan sebagai sosok yang bisa bergaul, menyenangkan, memikirkan orang lain, memiliki kedekatan dengan keluarga dan teman, mempunyai aktivitas dinamis dan kreatif, dan memiliki ide cemerlang untuk menyelesaikan masalah.

\section{UCAPAN TERIMA KASIH}

Artikel ini diangkat dari penelitian mandiri swadana yang dilaksanakan pada tahun 2009. Ucapan terima kasih disampaikan kepada mitra sejawat yang telah membantu kegiatan verifikasi dan triangulasi data dan hasil penelitian. Ucapan terima kasih juga disampaikan kepada Dr. Suhardi, M.Pd. selaku pengampu mata kuliah Analisis Wacana di Pascasarjana UNY yang telah 
memberi arahan, bimbingan aspek-aspek teroritik dalam kaitannya dengan kajian wacana.

\section{DAFTAR PUSTAKA}

Cameron, Lynne.2001.TeachingLanguages to Young Learners. Cambridge: Cambridge University Press.

Eriyanto. 2001. Analisis Wacana. Yogyakarta: LKis.

Fanani, M. dkk. 1995. Struktur dan Nilai Budaya dalam Cerita Berbingkai. Jakarta: Pusat Pembinaan dan Pengembangan Bahasa.

Yulianti, Febriana. 2003. "Karakteristik Ragam Cerita Anak sebagai Alternatif Pengajaran Apresiasi Sastra di Sekolah Dasar". Http:// digilib.itb.ac.id/gdl.php. Diunduh November 2009

Hurlock, E. B. 1978. Perkembangan AnakJilid 2 (terj.). Jakarta: Erlangga.

Lukens, R.J. 1999. A Critical Handbook of Children's Literature. New York: Longman.

Mixon, M. dan P. Temu. 2009. “First Road To Learning: Language Through Stories". English Teaching Forum. Volume 44, No 2, 2006.

Morrow, L.M. 1993. Literacy Development in the Early Years: Helping Children Read and Write. Boston: Allyn \& Bacon.

Nurgiyantoro, B. 2005. Sastra Anak:
Pengantar Pemahaman Dunia Anak. Yogyakarta: Gadjah Mada University Press.

Plaskota. J.L. "Beyond Literacy: The Influence of Reading and Stories on Children's Spiritual Formation". Http://www.dominican.edu/ query. Diunduh November 2009

Pollard, Nani. 2002. "Pengajaran bahasa indonesia untuk pembelajar asing melalu cerita tradisi lisan". Http:// www.ialf.edu/kipbipa/. Diunduh November 2009.

Richards, J.C. dan Rodgers. 2003. Approaches and Methods in Elt. Oxford: Oxford University Press.

Slattey, M. Dan J. Willis. 2003. English for Primary Teachers. Oxford: OUP.

Sobur, Alex. 2002. Analisis Teks Media. Bandung: PT Remaja Rosdakarya.

Rahayu, Sri. 2008. "Penanda Hubungan Repetisi pada Wacana Cerita Anak Tabloid Yunior Tahun 2007". Http://etd.eprints.ums. ac.id. Diunduh November 2009.

Sumarlam, dkk. 2003. Teori dan Praktik Analisis Wacana. Solo Baru: Pustaka Cakra.

Toha-Sarumpaet, Ririn K. 2004. "Sastra dan Anak: Penjajah dan Taklukannya". Yogyakarta: Hiksi. 